Received: 1.4.2011.

Corrected: 22.9.2011.

Accepted: 24.1.2012.

Online: 15.2.2012.

\title{
Interaction diagrams for reinforced concrete circular cross-section
}

\section{Authors:}

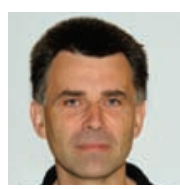

Željko Smolčič, M.Sc. CE Faculty of Civil Engineering University of Rijeka zeljko.smolcic@ri.t-com.hr

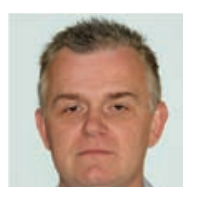

Davor Grandič, PHd.Sc. CE Faculty of Civil Engineering University of Rijeka davor.grandic@gradri.hr

\section{Željko Smolčić, Davor Grandič}

Subject review

\section{Interaction diagrams for reinforced concrete circular cross-section}

The procedure for creating interaction diagrams for reinforced-concrete circular crosssections, based on HRN EN 1992-1-1, is described in the paper. Due to introduction of new concrete strength classes, with somewhat different parameters for the stressrelative strain diagram, it has become necessary to develop new interaction diagrams. The computation procedure based on which circular cross section interaction diagrams were made for all concrete classes, was conducted. The use of these interaction diagrams will simplify dimensioning of reinforced-concrete circular cross-sections.

\section{Key words:}

reinforced concrete, dimensioning, circular cross-section, interaction diagrams

Pregledni rad

\section{Željko Smolčić, Davor Grandić}

\section{Dijagrami interakcije za AB kružni poprečni presjek}

U radu je opisan postupak izrade dijagrama interakcije za armiranobetonske kružne poprečne presjeke prema normi HRN EN 1992-1-1. Uvođenjem novih razreda čvrstoće betona s nešto drugačijim parametrima proračunskog dijagrama naprezanje-relativna deformacija dolazi do potrebe izrade novih dijagrama interakcije. Proveden je postupak proračuna temeljem kojeg su izrađeni dijagrami interakcije za kružni poprečni presjek za sve razrede betona. Primjenom dobivenih dijagrama interakcije pojednostavljuje se postupak dimenzioniranja armiranobetonskih kružnih poprečnih presjeka.

Ključne riječi:

armirani beton, dimenzioniranje, kružni poprečni presjek, dijagrami interakcije

Übersichtsarbeit

\section{Željko Smolčić, Davor Grandić}

\section{Interaktionsdiagramm für Stahlbeton-Kreisquerschnitte}

In der Arbeit wurde das Erstellungsverfahren des Interaktionsdiagramms für Stahlbeton-Kreisquerschnitte nach Norm HRN EN 1992-1-1 beschrieben. Mit der Einführung von neuen Betonfestigkeitsklassen mit etwas abgeänderten Parametern des Berechnungdiagramms führt die Spannung - relative Deformierung zu einem Bedarf an der Erstellung von neuen Interaktionsdiagrammen. Es wurde das Berechnungsverfahren durchgeführt, auf Grund welchem die Interaktionsdiagramme für den Kreisquerschnitt für alle Betonklassen ausgearbeitet wurden. Durch Anwendung der erhaltenen Interaktionsdiagramme wird das Dimensionierungsverfahren von Stahlbeton- Kreisquerschnitten vereinfacht.

Schlüsselwörter:

Stahlbeton, Dimensionieren, Kreisquerschnitt, Interaktionsdiagramm 


\section{Introduction}

New concrete strength classes, with the exception of concrete classes C12/15 to C50/60, are presented in HRN EN 1992 [1], and so new higher concrete classes are introduced: C55/67, C60/75, C70/85, C80/95 and C90/105. This means that, in addition to normal concrete strength classes, this standard takes into account a wider application of higher strength concrete classes, i.e. concrete classes with characteristic compressive cylinder strength of concrete [1] in excess of $50 \mathrm{MPa}$.

The high strength concrete is less ductile than the normal strength concrete and, consequently, the form of the stress - strain diagram becomes different for higher class concrete grades.

In addition, the definition of the design compressive strength of concrete is also different in HRN EN 1992 [1], when compared to HRN ENV 1992 [2].

Because of introduction of new concrete classes with a different stress - strain diagrams for higher class concrete types, it has become necessary to develop new interaction diagrams to enable design of reinforced-concrete circular cross sections with respect to the axial force and bending action. For the same reason, interaction diagrams for design of rectangular cross sections must also be developed. According to information available to the authors, an university course material with interaction diagrams for rectangular sections is soon to be published in Croatia by other authors. As to diagrams presently available in national literature in Croatia [3], we currently have interaction diagrams for circular cross sections according to Jevtić, developed in accordance with the Byelaw for Concrete and Reinforced Concrete [4].

Interaction diagrams for circular cross sections, based on HRN EN 1992-1-1, are already available in literature $[5,6]$ Interaction diagrams for circular cross sections, based on DIN 1045-1 [7], are presented in book [6]. Design stress strain diagrams for concrete, based on standards DIN 10451 and HRN EN 1992-1-1, are identical for concrete classes C12/15 to $C 50 / 60$. Interaction diagrams for circular cross sections according to DIN 1045-1 can be used in Croatia as approximations only, as they are defined as stress - strain diagrams for reinforcing steel with an inclined upper branch, according to DIN 1045-1.

Interaction diagrams available in literature [6] are conceived for the biggest relative deformation of tensile reinforcement $(0.025$ or $25 \%$ ), while in Croatia the value of $0.02(20 \%)$ is normally used.

For concrete classes higher than C50/60 the experimental diagrams for concrete and steel, based on DIN 1045-1 and HRN EN 1992-1-1 are not identical, which is why the interaction diagrams according to DIN 1045-1 can not be used in Croatia.
Interaction diagrams for circular cross sections, based on EN 1992, are given $n$ literature [5]. These diagrams are given for concrete classes C12/15 to C50/60, and are related to the zone of eccentric compressive load only.

Interaction diagrams for circular cross sections, based on HRN EN 1992-1-1, are presented in the paper for all classes of concrete, for both eccentric compressive load and tensile load situations. Interaction diagrams were generated using the computer program Mathcad 2001i [8].

\section{Design diagrams for concrete and reinforcing steel}

\subsection{Design diagram for concrete}

According to HRN EN 1992-1-1, the following expression is used to define the design compressive strength:

$f_{\mathrm{cd}}=\alpha_{\mathrm{cc}} \cdot f_{\mathrm{ck}} / \gamma_{\mathrm{C}}$

where:

$f_{\mathrm{ck}}$ - is the characteristic compressive strength of concrete, $\gamma_{\mathrm{C}}$ - is the partial safety factor for concrete,

$\alpha_{c c}$ - is the coefficient which takes into account long-term effects on compressive strength and unfavourable effects due to the way in which load is applied. The recommended value according to EN 1992-1-1, as accepted in Croatia's draft national annex, is $\alpha_{\text {cc }}=1,0$.

Note: Compressive stress and compressive strain values presented in this paper assume a negative sign, while tensile stress and tensile strain values assume a positive sign.

The stress - strain diagram for concrete, shown in Figure 1, is used for design cross sections with respect to axial force and bending. Compressive strain and compressive stress values for concrete are presented in Figure 1 as absolute values, according to HRN EN 1992-1-1 [1]. Concrete properties shown in Table 1 are also presented as absolute values [1].

The stress in concrete can be presented using the following expressions:

$$
\begin{array}{ll}
\sigma_{\mathrm{c}}=-f_{\mathrm{cd}}\left[1-\left(1-\frac{\left|\varepsilon_{\mathrm{c}}\right|}{\varepsilon_{\mathrm{c} 2}}\right)^{n}\right] & \text { for }-\varepsilon_{\mathrm{c} 2} \leq \varepsilon_{\mathrm{c}} \leq 0 \\
\sigma_{\mathrm{c}}=-f_{\mathrm{cd}} & \text { for }-\varepsilon_{\mathrm{cu} 2} \leq \varepsilon_{\mathrm{c}}<-\varepsilon_{\mathrm{c} 2} \\
\sigma_{\mathrm{c}}=0 \mathrm{MPa} & \text { for } \varepsilon_{\mathrm{c}}>0
\end{array}
$$

where $n$ is the exponent, $\varepsilon_{\mathrm{c} 2}$ is the strain, when the concrete strength has been achieved, while $\varepsilon_{\mathrm{cu} 2}$ is the ultimate strain value (Table 1). 
Table 1. Concrete properties according to HRN EN 1992-1-1

\begin{tabular}{|c|c|c|c|c|c|c|}
\hline & C12/15-C50/60 & C55/67 & $\mathrm{C} 60 / 75$ & C70/85 & C80/95 & C90/105 \\
\hline$f_{\mathrm{ck}}(\mathrm{MPa})$ & 12 do 50 & 55 & 60 & 70 & 80 & 90 \\
\hline$\varepsilon_{\mathrm{c} 2}(\%)$ & 2,0 & 2,2 & 2,3 & 2,4 & 2,5 & 2,6 \\
\hline$\varepsilon_{\mathrm{cu} 2}(\%)$ & 3,5 & 3,1 & 2,9 & 2,7 & 2,6 & 2,6 \\
\hline$n$ & 2,0 & 1,75 & 1,6 & 1,45 & 1,4 & 1,4 \\
\hline
\end{tabular}

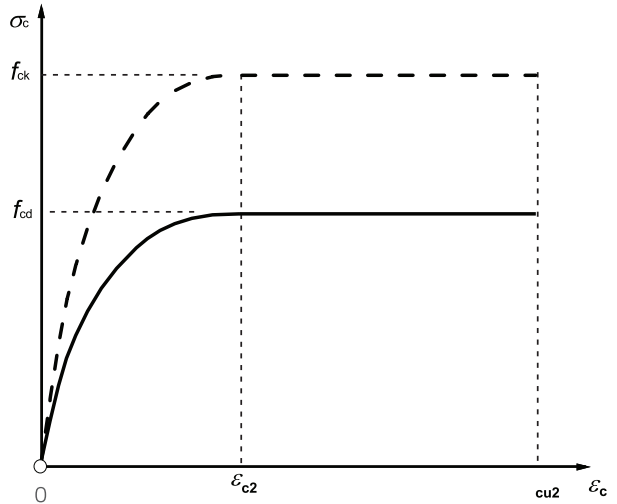

Figure 1. Stress - strain diagram for compressive stressed concrete

\subsection{Design diagram for reinforcing steel}

Stress - strain diagrams for reinforcing steel, which assume, according to HRN EN 1992-1-1, the same values in tension and compression, are presented in Figure 2.

According to HRN EN 1992-1-1, one of the following two assumptions (Figure 2) can be used in cross-section design:

a) inclined upper branch (in compression it is the lower branch) with limited strain $\varepsilon_{\text {ud }}$,

b) horizontal upper branch without the need to limit strain.

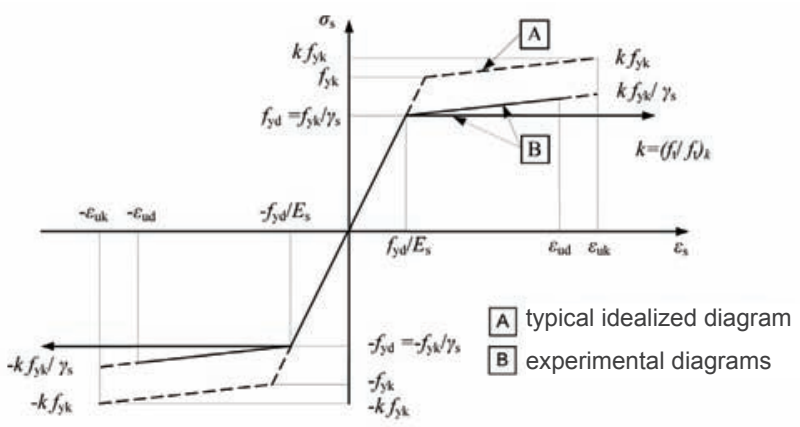

Figure 2. Stress - strain diagrams $\left(\sigma_{\mathrm{s}}-\varepsilon_{\mathrm{s}}\right)$ for reinforcing steel

In Figure $2, f_{\mathrm{yk}}$ is the characteristic yield strength of reinforcing steel, $f_{\mathrm{yd}}$ jis the design strength of reinforcing steel, $\left(f_{\mathrm{t}} / f_{\mathrm{y}}\right)_{\mathrm{k}}$ is the characteristic yield to tensile strength ratio, $\gamma_{\mathrm{s}}$ is the partial factor for reinforcing steel, and $\varepsilon_{\text {uk }}$ is the characteristic strain of reinforcing steel at maximum load. Figure 2 is valid for tensile and compression stresses and strains.
The experimental stress - strain diagram for concrete, with the horizontal top branch and with maximum strain $\varepsilon$ ud $=0.02$ (20 $\%$ ), was used as basis for developing interaction diagrams that are presented in this paper. The stress in reinforcing steel (according to Figure 2), for bilinear experimental diagram of steel with horizontal top branch (lower branch in case of compression), amounts to:

$\sigma_{\mathrm{s}}=-f_{\mathrm{yd}} \quad$ for $\quad-\varepsilon_{\mathrm{ud}} \leq \varepsilon_{\mathrm{s}} \leq-\varepsilon_{\mathrm{yd}}$

$\sigma_{\mathrm{s}}=\varepsilon_{\mathrm{s}} \cdot E_{\mathrm{s}} \quad$ for $\quad-\varepsilon_{\mathrm{yd}}<\varepsilon_{\mathrm{s}}<\varepsilon_{\mathrm{yd}}$

$\sigma_{\mathrm{s}}=f_{\mathrm{yd}} \quad$ for $\quad \varepsilon_{\mathrm{yd}} \leq \varepsilon_{\mathrm{s}} \leq \varepsilon_{\mathrm{ud}}$

where the elastic modulus for steel is $E_{\mathrm{s}}=200000 \mathrm{MPa}$, and $f_{\text {yd }}$ is the design yield strength of reinforcing steel.

\section{Interaction diagrams for circular cross sections}

The description of the circular cross section with reinforcement is presented in Figs. 3 and 5. The concrete strain in a given point is defined as:

$\varepsilon_{\mathrm{c}}=\varepsilon_{\mathrm{c}, \mathrm{ed} 2}+\kappa\left(\begin{array}{l}h \\ 2\end{array}+z\right)$

The cross-section curvature is defined using the following expression:

$\kappa=\frac{\varepsilon_{\mathrm{s} 1}-\varepsilon_{\mathrm{c}, \mathrm{ed} 2}}{d}$

where:

$\varepsilon_{\text {s1 }}$ - strain of reinforcement at the bottom edge in Figure 3,

$\varepsilon_{\mathrm{c}, \mathrm{ed} 2}$ - strain of concrete at the top edge in Figure 3,

$\varepsilon_{\mathrm{c}, \mathrm{ed} 1}$ - strain of concrete at the bottom edge in Figure 3,

$z$ - distance between the centre of gravity of concrete section and the point under study,

$h$ - total height of cross section (diameter),

$d$-distance between the top edge of concrete and reinforcement at the bottom edge,

$d_{1}$ - distance between the uniformly distributed reinforcement and the section edge.

As it is assumed in calculation that plane cross sections stay plane even after deformation (Bernoulli hypothesis of plane sections), all points of the deformed section will be situated in the same plane (plane of strain) which passes through the neutral 
axis of cross section and is inclined at $\kappa$ with respect to the undeformed plane of cross section. The strain of reinforcement in a given point of a circle where a longitudinal reinforcement is uniformly distributed is defined according to the following expression (Figs. 3 and 5).

$\varepsilon_{\mathrm{s}}=\varepsilon_{\mathrm{c}, \mathrm{ed} 2}+\kappa\left(\frac{h}{2}+z\right)=\varepsilon_{\mathrm{c}, \mathrm{ed} 2}+\kappa\left(\frac{h}{2}+r_{\mathrm{s}} \cdot \cos \alpha\right)$

where $r_{\mathrm{s}}$ and $\alpha$ are defined in Figure 5.

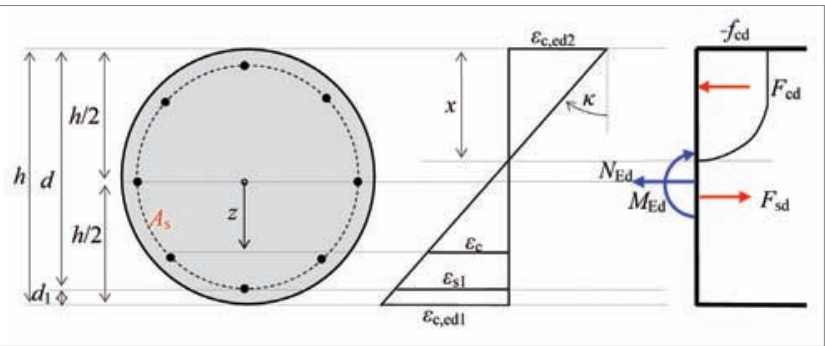

Figure 3. Circular cross section with distribution of strains, stresses and forces

As shown in expression (9) any one of the three values, i.e. $\varepsilon_{\mathrm{c}, \mathrm{dd} 2}, \varepsilon_{\mathrm{s} 1}$ or $\kappa$, can be defined if the other two values are known. To define the interaction diagram, two of these values $\left(\varepsilon_{\mathrm{c} \text {,ed2 }}\right.$ ,$\left.\varepsilon_{\mathrm{s} 1}\right)$ must be assumed, i.e. one has to vary the position of the deformation plane which defines strains and stresses in concrete and reinforcement.

Interaction diagrams can be used to design of cross sections subjected to compressive or tensional axial forces with bending moment. They can also be used to design of cross sections subjected to bending action without axial force, and cross sections subjected to axial force only. This dimensioning can be made in various positions of deformation plane. Zones of deformation plane for cross section of general shape are shown in Figure 4. Strain plane positions were varied by rotating the strain plane around axes parallel to neutral axis of cross section, and they pass through points $A$, B or C (Figure 4):

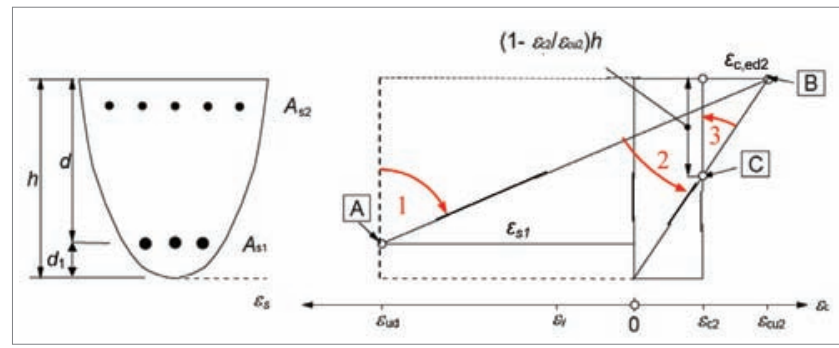

Figure 4. Possible strain distributions in reinforced-concrete of general shape according to (2)

Zone 1 (rotation around point A)

$\varepsilon_{\mathrm{s} 1}=\varepsilon_{\mathrm{ud}}$

$\varepsilon_{\mathrm{c}, \mathrm{ed} 2}$ varies from $\varepsilon_{\mathrm{ud}}$ to $\varepsilon_{\mathrm{cu} 2}$
Zone 2 (rotation around point B)

$\varepsilon_{\mathrm{c}, \mathrm{ed} 2}=-\varepsilon_{\mathrm{cu} 2}$

$\varepsilon_{\mathrm{s} 1}$ varies from $\varepsilon_{\mathrm{ud}}$ to $\left(-\varepsilon_{\mathrm{cu} 2} / \mathrm{h}\right) \cdot d_{1}$

Zone 3 (rotation around point C)

$\varepsilon_{\mathrm{c}, \mathrm{ed} 2}$ varies from $-\varepsilon_{\mathrm{cu} 2}$ to $-\varepsilon_{\mathrm{c} 2}$

$\varepsilon_{\mathrm{s} 1}$ varies from $\left(-\varepsilon_{\mathrm{cu} 2} / h\right) \cdot d_{1}$ to $-\varepsilon_{\mathrm{c} 2}$

The differential area of concrete is obtained according to Figure 5:

$d A_{\mathrm{c}}=b(z) \cdot d z=\left(2 \sqrt{r^{2}-z^{2}}\right) d z$

The differential area of reinforcement is defined according to Figure 5, under assumption that the reinforcement is uniformly distributed at the distance rs from the centre of gravity of the concrete section:

$d A_{\mathrm{s}}=\frac{A_{\mathrm{s}}}{2 \cdot r_{\mathrm{s}} \cdot \pi} d s=\frac{A_{\mathrm{s}}}{2 \cdot r_{\mathrm{s}} \cdot \pi}\left(r_{\mathrm{s}} \cdot d \alpha\right)=\frac{A_{\mathrm{s}}}{2 \cdot \pi} d \alpha$

The design compressive force in concrete is defined according to the following expresssion:

$F_{\mathrm{cd}}=\int_{A_{\mathrm{c}}} \sigma_{\mathrm{c}} \cdot d A_{\mathrm{c}}=\int_{-h / 2}^{h / 2} \sigma_{\mathrm{c}} \cdot\left[\left(2 \sqrt{r^{2}-z^{2}}\right) d z\right]$

The design force in reinforcement is calculated using the following expression:

$F_{\mathrm{sd}}=\int_{A_{\mathrm{s}}} \sigma_{\mathrm{s}} \cdot d A_{\mathrm{s}}=\int_{0}^{2 \cdot \pi} \sigma_{\mathrm{s}} \cdot\left(\frac{A_{\mathrm{s}}}{2 \cdot \pi} d \alpha\right)$

where:

$A_{\text {s }}$ - total area of reinforcement cross section,

$r$ - radius of circular cross section.

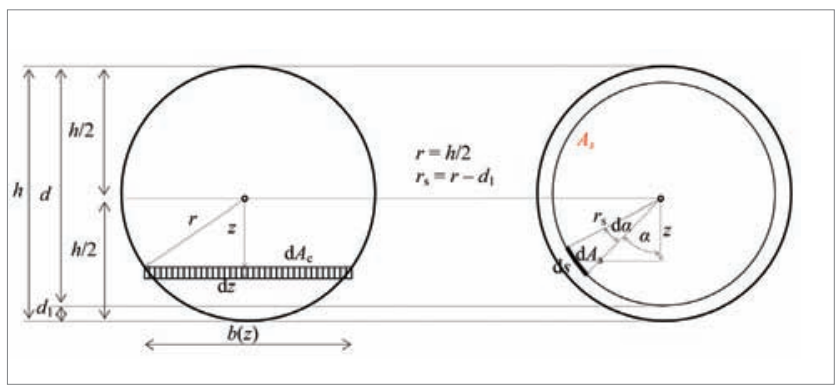

Figure 5. Differential areas of concrete and reinforcement

Two conditions must concurrently be met in sections that are simultaneously subjected to bending moment and axial force:

$N_{\text {Ed }} \leq N_{\text {Rd }}$,

$M_{\mathrm{Ed}} \leq M_{\mathrm{Rd}}$ ， 
where:

$N_{\text {Ed }}$ - design acting axial force,

$M_{\text {Ed }}$ - design acting bending moment,

$N_{\mathrm{Rd}}^{\mathrm{Ed}}$ - resistance of cross section to axial force action,

$M_{\mathrm{Rd}}$ - bearing moment of cross section.

The resistance of cross section to axial force action is:

$N_{\mathrm{Rd}}=F_{\mathrm{cd}}+F_{\mathrm{sd}}$

When expression (17) is inserted into the expression (15), we obtain:

$N_{\mathrm{Ed}} \leq F_{\mathrm{cd}}+F_{\mathrm{sd}}$

i.e. when expressions (13) and (14) are inserted for $F_{\text {cd }}$ and $F_{\text {sd }}$ into the previous expression (18), we obtain:

$N_{\mathrm{Ed}} \leq \int_{-h / 2}^{h / 2} \sigma_{\mathrm{c}} \cdot\left[\left(2 \sqrt{r^{2}-z^{2}}\right) d z\right]+\int_{0}^{2 \cdot \pi} \sigma_{\mathrm{s}} \cdot\left(\frac{A_{s}}{2 \cdot \pi} d \alpha\right)$

When the expression (19) is divided by the factor $A_{\mathrm{c} \times} f_{\mathrm{cd}^{\prime}}$ we obtain:

$\frac{N_{\mathrm{Ed}}}{A_{\mathrm{c}} \cdot f_{\mathrm{cd}}} \leq \frac{\int_{-h / 2}^{h / 2} \sigma_{\mathrm{c}} \cdot\left[\left(2 \sqrt{r^{2}-z^{2}}\right) d z\right]}{A_{\mathrm{c}} \cdot f_{\mathrm{cd}}}+\frac{A_{\mathrm{s}} \cdot f_{\mathrm{yd}}}{A_{\mathrm{c}} \cdot f_{\mathrm{cd}}} \frac{\int_{0}^{2 \cdot \pi} \sigma_{\mathrm{s}} \cdot\left(\frac{1}{2 \cdot \pi} d \alpha\right)}{f_{\mathrm{yd}}}$

where $A_{\mathrm{c}}=h^{2} \pi / 4$ area of the concrete cross section.

The dimensionless axial force $v_{\text {Ed }}$ and the mechanical reinforcement ratio $\omega$ are introduced into the expression (20):

$v_{\mathrm{Ed}}=\frac{N_{\mathrm{Ed}}}{A_{\mathrm{c}} \cdot f_{\mathrm{cd}}}$

$\omega=\frac{A_{\mathrm{s}} \cdot f_{\mathrm{yd}}}{A_{\mathrm{c}} \cdot f_{\mathrm{cd}}}$

and so for $N_{\mathrm{Ed}}=N_{\mathrm{Rd}}$ we obtain:

$\nu_{\mathrm{Ed}}=\frac{\int_{-h / 2}^{h / 2} \sigma_{\mathrm{c}} \cdot\left[\left(2 \sqrt{r^{2}-z^{2}}\right) d z\right]}{A_{\mathrm{c}} \cdot f_{\mathrm{cd}}}+\omega \frac{\int_{0}^{2 \cdot \pi} \sigma_{\mathrm{s}} \cdot\left(\frac{1}{2 \cdot \pi} d \alpha\right)}{f_{\mathrm{yd}}}$

The load bearing moment by which the cross section withstands the bending action amounts to:

$M_{\mathrm{Rd}}=\int_{-h / 2}^{h / 2} \sigma_{\mathrm{c}} \cdot z \cdot\left[\left(2 \sqrt{r^{2}-z^{2}}\right) d z\right]+\int_{0}^{2 \cdot \pi} \sigma_{\mathrm{s}} \cdot z \cdot\left(\frac{A_{\mathrm{s}}}{2 \cdot \pi} d \alpha\right)$

i.e.:

$M_{\mathrm{Rd}}=\int_{-h / 2}^{h / 2} \sigma_{\mathrm{c}} \cdot z \cdot\left[\left(2 \sqrt{r^{2}-z^{2}}\right) d z\right]+\int_{0}^{2 \cdot \pi} \sigma_{\mathrm{s}} \cdot\left(r_{\mathrm{s}} \cdot \cos \alpha\right) \cdot\left(\frac{A_{\mathrm{s}}}{2 \cdot \pi} d \alpha\right)$

Once the expression (26) is inserted into the expression (16) we obtain:
$M_{\mathrm{Ed}} \leq \int_{-h / 2}^{h / 2} \sigma_{\mathrm{c}} \cdot z \cdot\left[\left(2 \sqrt{r^{2}-z^{2}}\right) d z\right]+\int_{0}^{2 \cdot \pi} \sigma_{\mathrm{s}} \cdot\left(r_{\mathrm{s}} \cdot \cos \alpha\right) \cdot\left(\frac{A_{\mathrm{s}}}{2 \cdot \pi} d \alpha\right)$

and then the expression (27) is divided by the factor $A_{\mathrm{c}} \times h \times f_{\mathrm{cd}}$ :

$\frac{M_{\mathrm{Ed}}}{A_{\mathrm{c}} \cdot h \cdot f_{\mathrm{cd}}} \leq \frac{\int_{-h / 2}^{h / 2} \sigma_{\mathrm{c}} \cdot z \cdot\left[\left(2 \sqrt{r^{2}-z^{2}}\right) d z\right]}{A_{\mathrm{c}} \cdot h \cdot f_{\mathrm{cd}}}+\frac{A_{\mathrm{s}} \cdot f_{\mathrm{yd}}}{A_{\mathrm{c}} \cdot f_{\mathrm{cd}}} \cdot \frac{\int_{0}^{2 \cdot \pi} \sigma_{\mathrm{s}} \cdot\left(r_{\mathrm{s}} \cdot \cos \alpha\right) \cdot\left(\frac{1}{2 \cdot \pi} d \alpha\right)}{h \cdot f_{\mathrm{yd}}}$

The mechanical reinforcement ratio $\omega$ (expression (22)) and the dimensionless bending moment $\mu_{\mathrm{Ed}}$ are inserted into the expression (28):

$\mu_{\mathrm{Ed}}=\frac{M_{\mathrm{Ed}}}{A_{\mathrm{c}} \cdot h \cdot f_{\mathrm{cd}}}$

and so the algebraic connection between the dimensionless bending moment $\mu_{\mathrm{Ed}}$ and the mechanical reinforcement ratio $\omega$ is obtained for $M_{\mathrm{Ed}}=M_{\mathrm{Rd}}$ :

$\mu_{\mathrm{Ed}}=\frac{\int_{-h / 2}^{h / 2} \sigma_{\mathrm{c}} \cdot z \cdot\left[\left(2 \sqrt{r^{2}-z^{2}}\right) d z\right]}{A_{\mathrm{c}} \cdot h \cdot f_{\mathrm{cd}}}+\omega \cdot \frac{\int_{0}^{2 \cdot \pi} \sigma_{\mathrm{s}} \cdot\left(r_{\mathrm{s}} \cdot \cos \alpha\right) \cdot\left(\frac{1}{2 \cdot \pi} d \alpha\right)}{h \cdot f_{\mathrm{yd}}}$

The required cross section area of reinforcing bars, uniformly distributed at the distance $r_{\mathrm{s}}$ from the centre of gravity of concrete, is determined using the following expression:

$A_{\mathrm{s}}=\omega \frac{f_{\mathrm{cd}}}{f_{\mathrm{yd}}} A_{\mathrm{c}}$

The interaction diagrams shown in Figures 6 to 11 were calculated and developed using the equilibrium equations (24) and (30). The steel $\varepsilon_{\mathrm{s} 1}$ and concrete $\varepsilon_{\mathrm{c}, \mathrm{ed} 2}$ deformation (curvature $\kappa$ ) and the mechanical reinforcement ratio $\omega$ were varied, and the values $v_{\mathrm{Ed}}$ and $\mu_{\mathrm{Ed}}$ were calculated and inserted into the coordinate system $v_{\mathrm{Ed}}-\mu_{\mathrm{Ed}}$. Interaction diagrams were developed for the circular cross section and concrete classes C12/15 to C50/60, C55/67, C60/75, C70/85, C80/95 and C90/105, for the steel $\mathrm{B} 500$, and for the ratio of $d_{1} / h=0,1$. Parameters $d_{1}$ and $h$ are defined by the expression (9).

The equilibrium equations (24) and (30) were set up in such a way that they apply for all three cross section deformation planes (Figure 4). Analytical solutions for integrals contained in equations (24) and (30) were not derived as they would be too extensive considering the circular shape of cross section, and so interaction diagrams were calculated using the MathCad software through which numerical integrations were made.

The concrete stress values $\sigma_{\mathrm{c}^{\prime}}$ as given in expressions (24) and (30), were integrated along the entire height of the cross section, i.e. from $-h / 2$ to $h / 2$. The reinforcement stress values $\sigma_{\text {s }}$ as given in expressions (24) and (30), were integrated along the entire circle, i.e. from the angle $\alpha=0$ to $2 \pi$. Stress values for concrete were determined using expressions (2) to (4), while stresses in steel were defined according to expressions (5) to (7). 

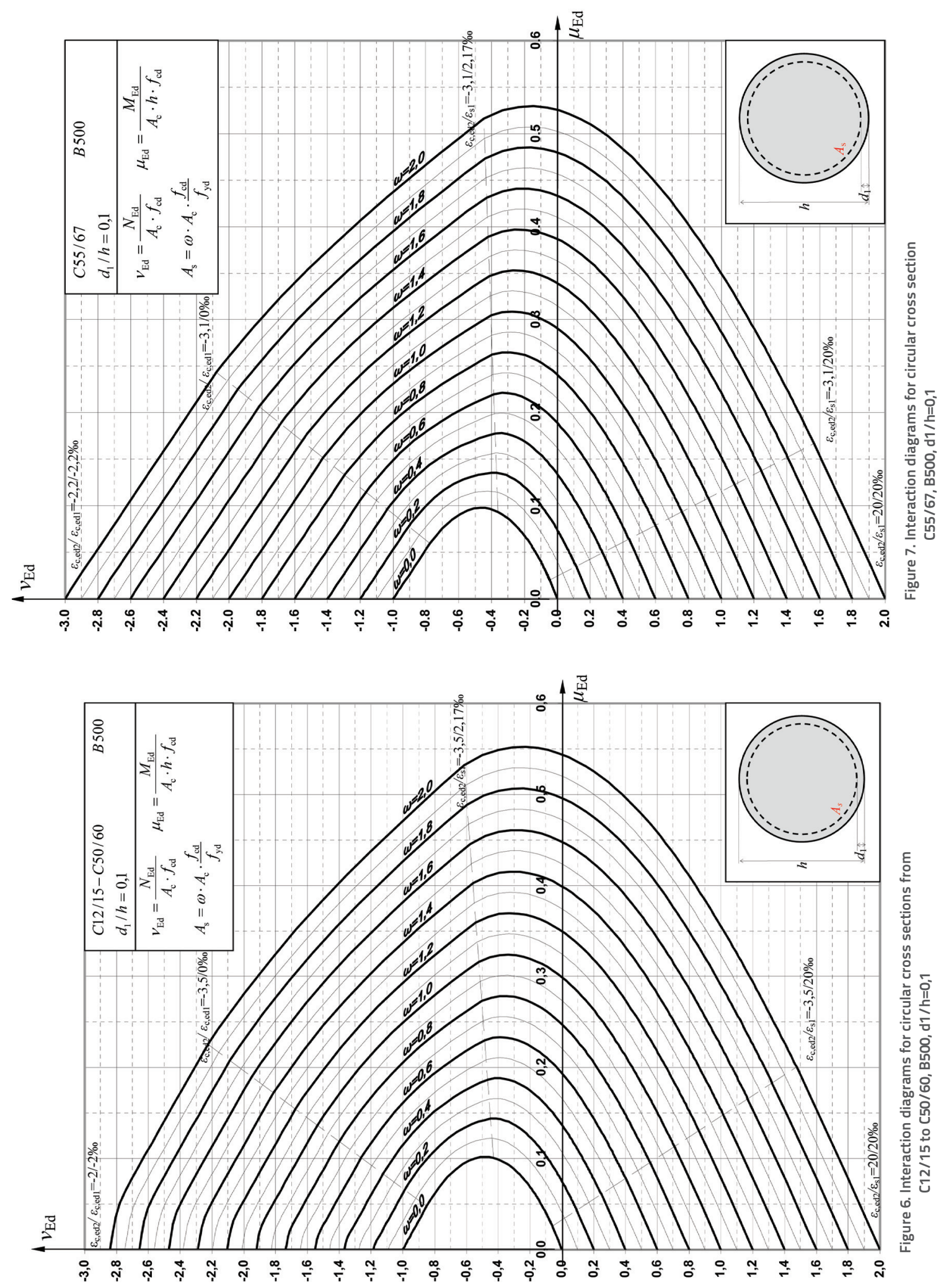

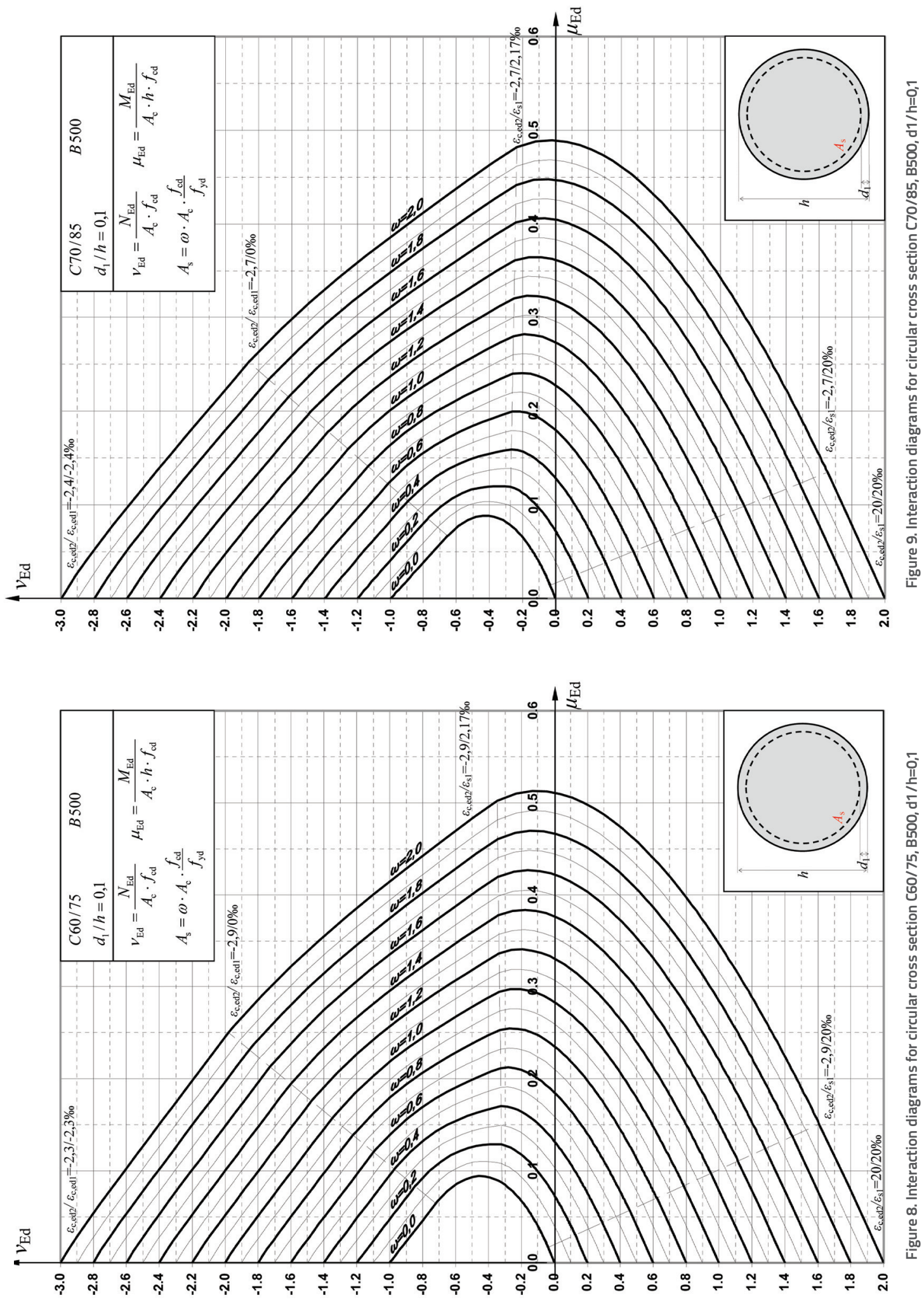

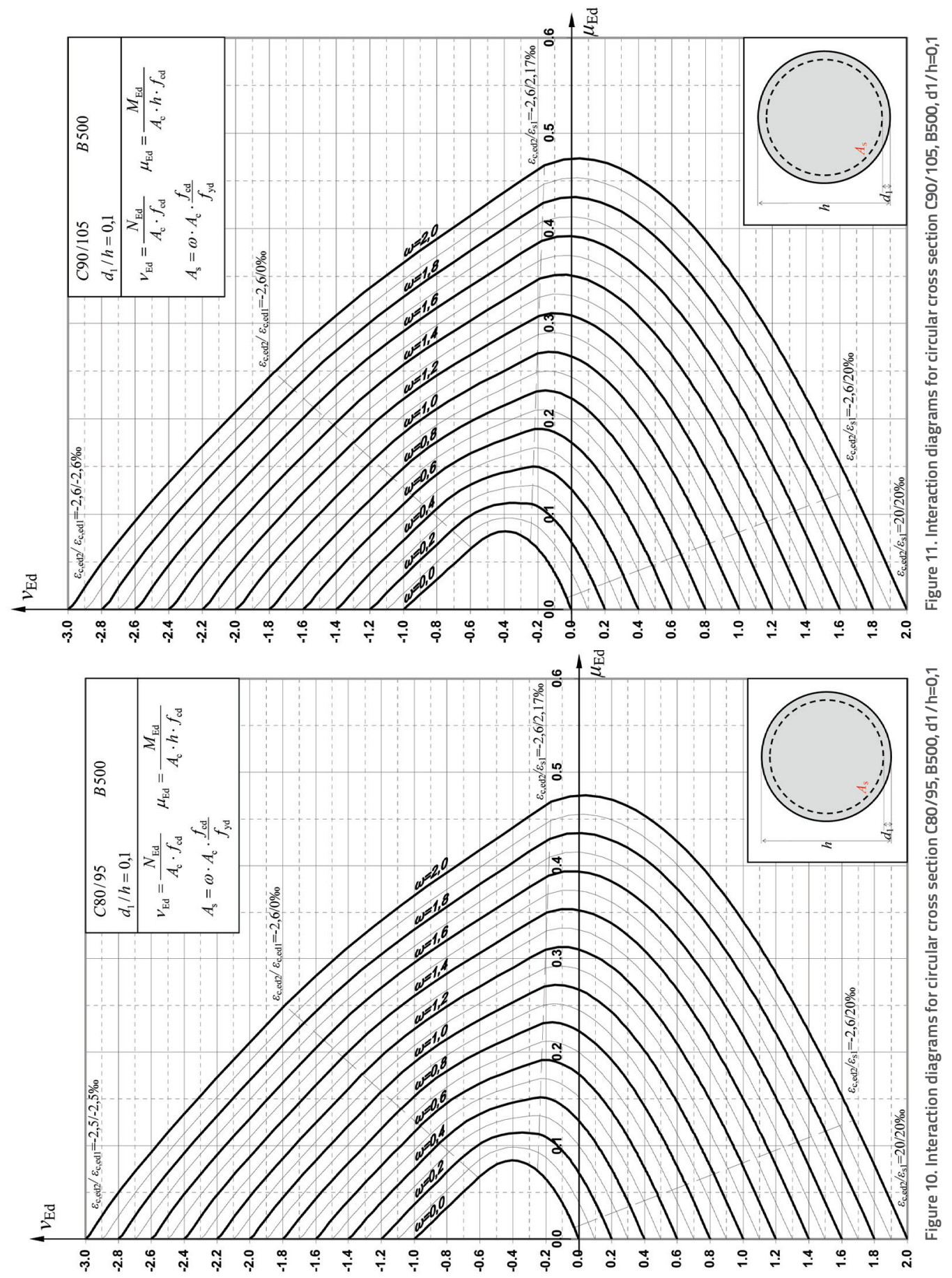

\section{Numerical example}

The circular cross section of the column $50 \mathrm{~cm}$ in diameter, with reinforcement uniformly distributed at the distance $\mathrm{d} 1=5 \mathrm{~cm}$ from the edge of the cross section, has to be dimensioned. The column will be made of concrete class C30/37 and reinforcing steel B500B. The cross section under study is subjected to the following design section forces: $M_{\mathrm{Ed}}=392 \mathrm{kNm} \mathrm{i} N_{\mathrm{Ed}}=-1570 \mathrm{kN}$.
Ratio:

$\frac{d_{1}}{h}=\frac{5}{50}=0,1$

The design compressive strength of concrete:

$f_{\mathrm{cd}}=\alpha_{\mathrm{cc}} \frac{f_{\mathrm{ck}}}{\gamma_{\mathrm{C}}}=1,0 \cdot \frac{30}{1,5}=20 \mathrm{MPa}$ 
The design yield limit of reinforcing steel:

$f_{\mathrm{yd}}=\frac{f_{\mathrm{yk}}}{\gamma_{\mathrm{s}}}=\frac{500}{1,15}=434,78 \mathrm{MPa}$

Cross section area:

$A_{\mathrm{c}}=\frac{h^{2} \cdot \pi}{4}=\frac{50^{2} \cdot \pi}{4}=1963,50 \mathrm{~cm}^{2}$

Dimensionless axial force - expression (21):

$v_{\mathrm{Ed}}=\frac{N_{\mathrm{Ed}}}{A_{\mathrm{c}} \cdot f_{\mathrm{cd}}}=\frac{-1570}{1963,50 \cdot 2,0}=-0,400$

Dimensionless bending moment - expression (29):

$\mu_{\mathrm{Ed}}=\frac{M_{\mathrm{Ed}}}{A_{\mathrm{c}} \cdot h \cdot f_{\mathrm{cd}}}=\frac{39200}{1963,50 \cdot 50 \cdot 2,0}=0,200$

The mechanical reinforcement ration is taken from Figure 6.:

$\nu_{\mathrm{Ed}}=-0,400 \quad \mu_{\mathrm{Ed}}=0,200 \quad \Rightarrow \omega=0,46$

The expression (31) is used to determine the required reinforcement area, uniformly distributed at the distance $r_{\mathrm{s}}$ from the centre of gravity of concrete:

$A_{\mathrm{s}}=\omega \frac{f_{\mathrm{cd}}}{f_{\mathrm{yd}}} A_{\mathrm{c}}=0,46 \frac{2,0}{43,478} 1963,50=41,55 \mathrm{~cm}^{2}$

The reinforcement percentage for the defined reinforcement is:

$\frac{A_{\mathrm{s}}}{A_{\mathrm{c}}} 100=\frac{41,55}{1963,50} 100=2,12 \%<4,0 \%$

(the biggest longitudinal reinforcement for columns $A_{\text {smax }}$ according to [1] amounts to $4 \%$ of $A_{c}$ )

The above circular section dimensioning example was checked using the computer software Gala Reinforcement 4.1 $\mathrm{e}^{\circledR}[9]$. The Gala Reinforcement $4.1 \mathrm{e}^{\circledR}$ software is used for dimensioning reinforced-concrete cross sections of arbitrary shape, subjected to uniaxial or biaxial bending with axial force. The neutral axis position is defined by the software through a theoretical and highly accurate iterative procedure aimed at meeting equilibrium conditions for acting and internal forces, based on surface integrals. It was determined by the said software, which can be used as a reference, that the cross section area of the reinforcement is $41,76 \mathrm{~cm}^{2}$ (36 reinforcing bars), with $\varepsilon_{\mathrm{c}, \text { ed } 2}=-3,5 \%, \varepsilon_{\mathrm{s} 1}=2,612 \%$ and $\mathrm{x}=25,77 \mathrm{~cm}$ ( $\mathrm{x}$ is the height of the cross-section compression area). It can be seen that the difference with respect to reinforcement determined via interaction diagrams is negligibly small.

\section{Conclusion}

Interaction diagrams for circular cross sections according to HRN EN 1992-1-1 are presented for all concrete classes. The advantage of the equilibrium equations presented in the paper is that they are valid in all deformation areas of the cross-section, and are adapted for use with computer programs for calculation procedures programming, such as the MathCad software.

A disadvantage of the described procedure used to be a relatively long time needed to calculate interaction diagrams, as the integrals of stress in concrete have to be calculated for every position in the strain plane. However, this is no longer considered a problem due to high speed of present day personal computers so that currently the interaction diagrams for one concrete class can be calculated via personal computer in about ten seconds.

The interaction diagrams can be used quite simply and with sufficient accuracy to design of circular cross sections of reinforced concrete. Circular cross sections are often encountered in practice as many columns presently used in buildings and bridges are of circular cross section. Although many commercial computer program packages can calculate and automatically design of reinforced-concrete structures, it is still necessary to use design tools such as interaction diagrams. Interaction diagrams can inter alia be used as a highly welcome tool for checking accuracy of dimensioning made using computer software packages where programming procedures are often impaired by certain initial simplifications and interpretations of standards and reinforced-concrete structure theories that are unknown to users.

\section{REFERENCE}

[1] HRN EN 1992-1-1, Eurocode 2: Design of Concrete Structures -Part 1-1: General Rules and Rules for Buildings (EN 1992-1-1:2004+AC:2008) (according to EN1992-1-1:2004), HZN, Zagreb. 2008. (in English)

[2] HRN ENV 1992-1-1, Eurocode 2: Design of Concrete Structures -Part 1-1: General Rules and Rules for Buildings (according to ENV 19921-1:1991), DZNM, Zagreb, 2004. (in English)

[3] Tomičić, I.: Manual for the Design of Reinforced-Concrete Structures, DHGK, Zagreb, 1993. (in Croatian)

[4] Byelaw on Technical Standards for Concrete and Reinforced-Concrete, Official Gazette No. 11/87. (in Croatian)

[5] Narayanan, R. S.; Beeby, A.: Designer's Guide to EN 1992-1-1 and 1992-1-2, Thomas Telford, London, 2005.
[6] Zilch, K.; Zehetmaier, G.: Bemessung im konstruktiven Betonbau Nach DIN 1045-1 (Fassung 2008) und EN 1992-1-1 (Eurocode 2), Springer, Berlin, Heidelberg, 2010.

[7] DIN 1045-1: Tragwerke aus Beton, Stahlbeton und Spannbeton; Teil 1: Bemessung und Konstruktion, Betonkalender 2009, Ernst \& Sohn, Berlin, 2009.

[8] Mathcad 2001i - User's Guide with Reference Manual, 2001, MathSoft Engineering \& Education.

[9] Alashki, l.: Computer program Gala Reinforcement 4.1 $e^{\varpi}$, Alashki.e.c Group, Sofija, Bulgaria, 2010. 